\title{
CREATIVE APPROACH TO SHAPING THE SYMBOLIC SYSTEM OF GLOBAL CULTURE
}

\author{
Yulia Pavlovna TEN (iD * \\ Department of Management and Innovation, Higher School of Management, \\ Financial University under the Government of the Russian Federation, \\ 49 Leningradsky Prospekt, 125993 Moscow, Russia
}

Received 3 May 2020; accepted 27 March 2021

\begin{abstract}
The key idea of the paper consists in suggestion that globalization focuses on the integration of different cultures under the umbrella of common ideas, norms and values. The globalization's challenge is the necessity of searching the ways and methods of overcoming the intercultural barriers among different peoples. The purpose of the research is to analyze the issue of creating a symbolic system global culture, the access to cultural code of this system will help the participants of intercultural communication to minimize the barriers that prevent the mutual understanding. The author guesses that symbols can be seen as the creative technology for shaping universal layer of a global culture. To access this "layer" of a global culture, communication subjects must have a common cultural code. The creative information and communication technologies help subjects of intercultural communication to be able to reveal the cultural codes of other cultural systems. The author puts forward the idea of the need for shaping of the universal "cultural knowledge network" on creative digital platform. The knowledge of the symbol system of a global culture can help all peoples to open new perspective of transcultural communication in the context of creating common non-verbal language for mutual understanding.
\end{abstract}

Keywords: creative technologies, cultural code, culture, intercultural barriers, intercultural communication, global culture, symbol, symbolic system of global culture.

\section{Introduction}

Globalization reflects a historical trend of human society evolution. It presents an objective process of increasing interaction between countries and peoples. Globalization inevitably involves peoples in the "network society" (Castells, 2010), namely to the global interconnected whole. This unity is supra-national and has certain principles, norms and standards of functioning. In this connection, the scholars offer the concept of "global community". The conception of "global community" assumes that the peoples who form the society within and outside of a physical space and "who subscribe to a diverse range of norms and

${ }^{\star}$ Corresponding author. E-mail ypten@fa.ru

Copyright (C) 2022 The Author(s). Published by Vilnius Gediminas Technical University

This is an Open Access article distributed under the terms of the Creative Commons Attribution License (http://creativecommons. $\mathrm{org} / \mathrm{licenses} / \mathrm{by} / 4.0 /$ ), which permits unrestricted use, distribution, and reproduction in any medium, provided the original author and source are credited. 
values that inform their visions and perspectives about the world" (Patel et al., 2011, p. 5). Metaphorically speaking, McLuhan (2002) puts forward the idea that all world is becoming as the global village. The "global village" is a symbolic metaphor of creative space in which the world turns into a kind of village, literally becoming smaller and giving its inhabitants of the village (average, understandable to most) way of thinking. New kind of world society, the network community is grounded on "the hyper-connectivity" (Floridi, 2015). Certainly, the influence of globalization on economy, social and cultural sphere leads to the accepting of the new system of ideas, norms, patterns and values by the contemporary societies.

If we consider globalization as a socio-cultural phenomenon, the essence of this phenomenon can be clarified in terms of the theory of intercultural communication. The basis of the contemporary approach to the globalization analysis in the context of international communication was laid by Luhmann (1997), Robertson (2000), Giddens (1986), Gudykunst (1997) and other researchers. Thus, in the works of $\operatorname{Kim}(1988,2005)$, the explanation of the hidden determinants of social processes observed in globalized societies is presented through the prism of the theory and practice of intercultural communications. The idea of communication as a central characteristic of cross-cultural processes was developed by Casrnir (1999), E. T. Hall and M. Reed Hall (1987), S. Hall (1997), Samovar et al. (2017), Sitaram (1976), and Stewart (1973). Globalization is interpreted as the process that creates interdependence among societies and cultures that were previously historically divided (Ferguson, 2012). Hence, Huntington (1997), Inglehart (2018), Hofstede (1984), Schwartz and Sagie (2000), and Triandis (2018) deal with clustering countries according to certain criteria, identifying, first of all, how other cultures are different from the Western one.

A few decades of thorough research into intercultural communication indicate the relative difficulty in establishing effective communication between various ethno-linguistic and religious communities (Dodd, 1977; Huntington, 1997; Gokmen, 2019; M. Guirdham \& O. Guirdham, 2017; Inoguchi, 2007). The participants of communication should overcome the cultural barriers: ethnic stereotypes, unfamiliar customs and strange practices, cultural differences in verbal and nonverbal communication styles in order to achieve successful intercultural understanding (Gudykunst, 1997; Hall \& Reed Hall, 1987; Hurn \& Tomalin, 2013; Morain, 2001; Patel et al., 2011). As a result, language and cultural barriers often have evaluative and affective consequences for participants in an intercultural context (Samovar et al., 2017; Sitaram, 1976). Despite the accumulated experience in the academic literature concerning recommendations for overcoming intercultural barriers, modern participants of international communication still do not manage to reach complete understanding.

Undoubtedly, the main objective of globalization is to achieve mutual understanding in order to find solutions to similar problems faced by global society and avoid different threats such as environmental disasters, pandemics, military conflicts, threat of famine, terrorism, etc. How can we achieve mutual understanding when the world is so diverse? This is urgency, especially today, when in 2020 the world was faced with the global threats. Not for nothing, yet Beck (2008) thought that the globalization contributes to the formation of "world risk society". In 2020, globalization has posed a new challenge to mankind, that is, the challenge of human survival in the face of the threat of the pandemic. In 2020-2021 years, many countries decided to lockdown, to impose restrictions on interaction with other states 
and regions of the world. The need to find answers to the challenges of globalization leads to the realization of the relevancy to involve the increasing number of various countries in the common space of international communication.

Culture can be seen as the semiotic system (Barthes, 1994; Lotman, 2001). To decipher the meanings and values of the foreign cultures, the participant of intercultural communication needs knowledge and understanding of the cultural codes of other cultures. In current situation of survival problems all nations and communities it is inevitable to search for a generally valid cultural code. Such cultural code makes it easier for participants of international communication to coordinate their positions in solving various pressing issues. The need to find answers to the challenges of globalization leads to the awareness of the need to involve an increasing number of cultures in the single space of meanings and values of a global culture.

Remarkably, Hall and Reed Hall pointed out: "Communication is culture, and culture is communication" (1987, p. 16). The important driver of the process of shaping symbolic system of a global culture is the subjects of communication who are engaged in creative thinking. Creativity can be understood as a process where participants of the intercultural communication are able overcome any communication barriers. It is worth to underline that currently it is important to develop the idea of creativity as the one of the basis values of the "creative society" (Kačerauskas, 2017; Stasiulis, 2017). Creativity gives the opportunity to analyse of foreign culture not as stranger but as culture with unique cultural code.

The purpose of the research is to analyze the issue of creative shaping a symbolic system of a global culture, the access to cultural code of this system will help the participants of intercultural communication to minimize the barriers that prevent the most effective mutual understanding. In this context the structure of a global culture is interpreted as a system of the local, national and regional cultures of a human civilization at whole.

\section{Methodology}

The research has an interdisciplinary approach, taking into account notions, approaches and methods of the information-semiotic conception of culture and the symbolic interactionism. The author also based on the methodology of analytical philosophy with an emphasis on symbolic theory. In particularly, for the research task is used to hermeneutical analysis.

\section{Culture as a system of various codes}

As Geertz (2017) notes, culture is "a set of meanings". Importantly that the concept of meaning is the key to the explication of culture. Culture can be considered as coherent "map of meaning" (Hall, 1997), through which a person is guided in the environment. S. Hall argues that

"the question of meaning arises in relation to all the different moments or practices in our 'cultural circuit' in the construction of identity and the making of difference, in production and consumption, as well as in the regulation of social conduct" (1997, p. 4). 
Each culture is a hierarchically structured system of different codes. Code is the system that sets the particular configuration of signs and symbols; rules for their combination; and the correspondence of each sign and symbol to the signified (Eko, 2006). The code of culture is the conventional symbolic system that embodied information about human being, society and environment as the result of process of categorization and conceptualization. The codes of culture act as the coordinate system for the person in the entire spectrum of his/her communications. Understanding of cultural meanings depends on an individual's ability to recognize the cultural code and the skills to build communication links.

In terms of information-semiotic approach, the main way to overcome the communication barrier (not natural or mechanical) is the ability and skills of the recipient on their own or through any other means (translator, electronic translator, etc.):

- to recognize the difference between the code of your own culture and the code of the participant from other culture;

- to translate the code of other people's culture into the language of your own culture (verbally and non-verbally);

- to perform a reverse response in accordance with the meanings of the code system of the participants from other people's culture;

- to develop the common realm of meanings and values of mutual understanding among intercultural communication participants on the basis of semiotic exchange.

It is also worth saying that cultural subjects (individuals, group, community, society) will find a greater mutual understanding if cultural differences are minimized. A vivid illustration is the socio-cultural policy of the European Union (EU) to create a single system of symbols of the united Europe (Fornäs, 2012). In this case, symbols are significant creative technology for creating European supra-national identity (Ten, 2014). Therefore, for any intercultural research addresses the intercultural communication it is mostly relevant to focus on differences and similarities in processes and behaviors both at different levels (local, regional, national) of one culture and across different cultures.

The critical analysis of the academic literature (Fornäs, 2012; Foret, 2009; Laffan, 1996; Manners, 2011; Theiler, 2006) reveals also that symbols, considered as tools of social technologies for constructing collective identity. They play an important role in the policy of a number of states, including EU (Merelman, 2018). For example, Fornäs explores the official symbols of the EU (flag, anthem, motto, Europe Day). He concludes that these symbols are the "keys of Europe" and help to form a collective supranational European identity (Fornäs, 2012, p. 56). Thus, symbols can play the relevant role in the special symbolic politics shaping the system of symbols of collective identity.

Surely, the values are the basic of the elements of each culture and civilization (Hofstede, 1984; Huntington, 1997; Inglehart, 2018; Gokmen, 2019). Meantime the clash of values across civilizations does not always mean the clash of civilizations (Inoguchi, 2007, p. 245). At the same time, the transformation of the symbolic system of any culture is a signal of the social needs of the future value's changes. It is interesting to note that today in the political life of many countries, symbols are the important creative marker for the expression of the political views and the values (for example, red rose as a symbol of the rose revolution in Georgia). In 2020, Belarus has been beginning a process of heated public discussions about the need to change the state symbols. It is known that state symbols are the technology of 
forming a collective national identity. Namely, creative approach can help to participants of intercultural communication to achieve more better agreement of meanings. Certainly, in the socio-cultural and the political-economic epochs of transition, national and state symbols are transformed or rejected. Importantly, the Law of the Republic of Belarus No. 83-Z of January 4, 2021 "On Amendments to the Law of the Republic of Belarus" about "On State Symbols of the Republic of Belarus" (Zakon Respubliki Belarus', 2021) introduced new amendments to the image of the state emblem. The new coat of arms is more creative and it has some differences from the previous one, which had roots connected with period of Soviet Union. Particularly, on the central symbol of a terrestrial globe is presented the map of Western Europe and the Atlantic Ocean, a politically pointed change from the previous picture, which has showed more territory of Eurasia.

\section{Symbolic basis of intercultural communication}

Any development of society is impossible without fixing the results of cognitive creative activity of human being, as well as the achievements of spiritual and material culture, without storing, accumulating and transmitting knowledge and experience in time and space. The information-semiotic approach allows to present culture as social information that is stored and accumulated by means of symbols created by human community. The world of culture represents itself in three aspects: the world of artifacts, the world of meanings, and the world of signs and symbols. Therefore, culture is an informational-semiotic system, a set of "texts". The text of culture is a sign-symbolic system (Lotman, 2001). Hence, intercultural communication is interpreted as the exchange of messages ("texts") between different cultures. Each cultural text is written in a specific language. A language of culture is "a set of common symbols or signs that a joint group of people have mutually agreed to create meaning" (Samovar et al., 2017).

It should underline that namely symbol is the unique socio-cultural phenomenon. Firstly, Cassirer (1955) stressed the need and importance of developing the concept of "symbolic forms". The origin of human culture is associated with the ability to symbolize (White, 1940). According to Cassirer (1955), the basis of human existence in the world is operations with symbols. Symbol is a sense-perceived form for expression of ideas, ideals, beliefs, norms, patterns, values of culture. "A symbol is anything that carries a particular meaning recognized by people who share culture" (Macionis, 2014). Symbol is a bridge connecting the visible with the invisible. Significantly, Jung (1980) thinks that cultural symbol is the form of expression collective unconscious. As symbols are interrelated subjective world and objective world, they give meanings to things, phenomena and processes. Lévi-Strauss believes that people communicate with each other using symbols and signs. Everything is a symbol or sign that acts as an intermediary between two subjects (Lévi-Strauss, 1974). As Ferraro and Andreatta (2018) write: "Symbols tie together people who otherwise might not be part of a unified group". In the symbolic interactionism, a person learns culture through symbolic meanings in the process of socialization. The objects of the physical and social worlds are considered, distinguished, systematized, interpreted and assigned meanings in the process of social interaction (Charon, 2009). Peoples and Bailey (2015) explain the link between symbols and 
culture. When a person learns ideas, norms and values in the process of socialization, he/she recognizes the meanings that people in his/her culture attach to symbols. The understandings people share about meaning of symbols affect the patterns of behavior rooted in the particular culture. Factually, if individuals did not agree that certain kinds of behaviors using special meanings; "social interaction would be far more difficult than it usually is" (Peoples \& Bailey, 2015). Symbol is

"[...] language that enables you to share the speculations, observations, facts, experiments, and wisdom accumulated over thousands of years - what culture is learned in a variety of ways and from a host of sources" (Samovar et al., 2017).

Definitely, symbols preserve and transmit elements of culture in- and inter-communicative processes. Symbol as a form of significant cultural content is a mechanism of intercultural communication among different participants in historical, cultural and spatial dimensions. Actually, intercultural communication is based on the process of symbolic interaction between individuals and groups belonging to different cultures (Samovar et al., 2015). Intercultural differences can be interpreted as differences in verbal and non-verbal codes in a specific context of communication (Casrnir, 1999; Geertz, 2017; Hall \& Reed Hall, 1987). Samovar et al. (2015) illustrate the process of how the meaning of a message changes when it is encoded by a person in one culture and decoded by a person in another. Accordingly, intercultural communication can be seen as a process of exchanging the symbols among cultures. The issue of realization of cultural differences of subjects of intercultural communication lays in their abilities to interpret the symbol of the strange culture in the correctly. If subjects of communication have few cultural differences, variants of interpretation of symbol must be insignificant.

\section{The globalization's language of symbols}

Globalization intensifies the need to communicate dissimilar minds and ways of thinking from various cultures in the world. Now different barriers are getting in the way of globalization process and obstruct effective intercultural communication. Some of these barriers are quite difficult to overcome (first of all, the model of thinking that has been formed in the particular culture, the system of traditional values, the understanding of reality, so on), while others can be circumvented by changing worldviews and socio-cultural conditions. While globalization is not totally able to unify the cultural codes of different cultural systems, one of the global trends is to create supranational transparent universal cultural code which facilitates or at least does not impede communication. The author puts forward the idea that globalization needs a special common language to achieve mutual understanding of the participants in intercultural communication. For this reason, namely symbols can be seen as relevant creative tools, which help to get the participants of interaction the common cultural code of a global culture.

The author's analysis of academic literature on the issue of the symbol allows us to draw the following conclusion. Each culture has certain symbols, which are crucial to its distinctive characteristics. At the same time the result of the long historical communication between different cultures is the forming the common symbols which have conventional nature. Such 
symbols can be named as "key symbols" (Ortner, 1973), "core symbols" (Schneider, 1980), "dominant symbols" (Turner, 1970), "condensation symbols" (Graber, 1976), "symbolic vehicle of meanings" (Swidler, 1986). Noteworthy the condensation symbols can be seen as the special symbols, which condense a broad range of ideas and meanings into a single form; exhibit a close connection with other related symbols. They are well connected in a network of meaning primed by the context (James \& Steger, 2014).

Thus, under the influence of globalization processes, as a result of intercultural communications of various participants of interaction (individuals, social groups, communities, institutions and organizations), generally the layer of symbols of world culture has been forming. In this context, this layer of a global supranational culture is considered as a system of ideas, ideals, beliefs, concepts, values, norms that are expressed in the form of symbols. What does it mean? Most of the countries around the world agree to assign certain meanings and values to these symbols. Examples are the United Nations Educational, Scientific and Cultural Organization (UNESCO) "Declaration of Principles on Tolerance" (1995), "Universal Declaration of Human Rights" (1948), United Nations (UN) "The Treaty on the Non-Proliferation of Nuclear Weapons" (2020), and others. Traffic signs, medical emblems, symbols of religion (Dreyfuss, 1984), coats of arms and flags of states and organizations, etc. become generally significant elements of the international symbolic environment. The brands are also the elements of the system of a global culture (Stratton \& Northcote, 2016).

The leaders of states, interstate unions (for example, EU, Eurasian Economic Union, etc.), the international organizations (UN, UNESCO, World Trade Organization, World Customs Organization, World Meteorological Organization, etc.), clubs (Group of Seven, Group of Twenty, the members of five major emerging economies (Brazil, Russia, India, China, and South Africa), etc.), strategic alliances play the significant role in forming, fixing and conveying common values for such global symbols. From 2020 to current day, a huge role in international communications in terms of developing a common code for mutual understanding plays the World Health Organization.

Hence, symbol can serve as universal non-verbal means of intercultural communication. Indeed, shaping a symbolic system of the global culture, the access to which will help the participants of intercultural communication to minimize the barriers that prevent the most effective mutual understanding. The system of symbols of global culture has different levels: the local level (symbols of cultures of individual social groups, communities, organizations, institutions and states), the regional level (symbols of regional countries, international unions, transnational companies), the world level (symbols meanings of which are generally significant for all subjects of intercultural communication). All together, these "core", "key", "condensation" symbols have been shaping the special layer in the structure of the global culture of humanity.

It is worth noting that the world layer of common symbols of a globe culture has been forming in the process of continual cross-cultural communications between different cultures. Every country, every people, every social group and individual can creative contribute to the formation of a symbolic system of a global culture. The mutual understanding of peoples, nations and cultures provides a complex unity of all human cultures. In order to be able to join the heritage of world culture, it is necessary for an increasing number of people 
of various races, religions, nationalities, and countries to learn and use the shared cultural code. It is urgently to search the creative technologies of formation of a common non-verbal symbolic language of international communication.

\section{The role of digital technologies in breaking intercultural communication barriers}

It should be note that globalization is the multidimensional process of forming the human community on the global scale, in conditions of openness and elimination of different barriers to the establishment of material, intellectual, spiritual, ethical, aesthetic and other forms of communication between peoples. Globalization offers the idea of the post-industrial, network, Internet, digital civilization. All countries as the participants of international communications are forced to create a third reality - digital. One of the creative technical means to facilitate mutual understanding in the discussion of global problems is information and communication technologies (including digital technologies). In fact, the information and communication technologies break the paradigm of social development, change the image and lifestyle of individuals, groups and communities (Betancourt, 2015; Floridi, 2014). Such technologies "deeply impact the human society" (Floridi, 2015). Furthermore, new creative technologies help to offer new sight on various social problems (Melnikas, 2019). First of all, the unified digital civilization forms the condition for breaking down any language barriers. It is not coincidence that a number of the latest innovative technologies are called "disruptive" and "breakthrough". With the spread of the Internet, there are increasingly more resources, that can be accessed through the network. The online versions of many electronic dictionaries are available, including those that can be supplemented by users (for example, Multitran.com, 2020). The Internet has connected translators living in different countries of the world. Every day there are more forums, blogs, and resources for translators, where the latter can share their experiences and help each other. One of the most famous of these sites are Proz.com (1999-2020b), KudoZ (Proz.com, 1999-2020a), Translatorscafe.com (2002-2020) and Translatorsbase.com (2002-2020). As a matter of fact, digital technologies contribute to cracking socio-cultural codes. For examples, a number of computer-assisted translation software and websites exist for various platforms and access types (Wordfastcom (2020), Sdltrados.com (2020), computer program Déjà $V u$, translation tools $S D L X$, so on).

Thus, the upcoming fourth industrial revolution, which is actively introducing new information and communication technologies, radically and dramatically changes the way of life and activities of modern individuals, groups and societies of the 21 st century. In the era of globalization, the digital revolution offers the opportunities for expanding the spaces and flows of cross-cultural communication, changing the key structure of intercultural communication. Due to new information and communication technologies, ideas, symbols, knowledge and skills accumulated by a particular society and culture are widely distributed to other socio-cultural systems.

However, the issue of "flow" of information in terms of the concept of Big Data leads, on the one hand, to an expansion, and on the other - to a decrease in opportunities for 
achieving mutual understanding. The fact is that in the era of development of information and communication technologies, new barriers appear in intercultural communication, which did not exist before the Fourth Industrial Revolution. For example, computer translation technologies and machine translation allow a contemporary person to get the acceptable quality of foreign texts. They demonstrate "the growing need for innovative technological solutions to the age-old problem of the language barrier" (Doherty, 2016, p. 947). However, machine translation and computer-assisted translation tools of the foreign text does not yet guarantee the achievement of effective intercultural understanding. The fact is that each word or expression of a culture potentially contains different levels for interpretation (Geertz, 2017) by the participants of intercultural communication. In this connection, it is important to remind about symbol. On the one hand, each symbol potentially obtains a number of different meanings. That is why its interpretation is depended of the particular context of that symbol's using. On the other hand, the meanings of symbols are arbitral and conventional (Charon, 2009). Exclusively, creative approach can help to forming international globalization's language of symbols. Therefore, creativity is an ability that needs to be developed in modern society. Creativity is the ability to find the means to overcome cross-cultural barriers. It "arises from the interaction between an individual's thinking and a socio-cultural context” (Braslauskas, 2020).

\section{Results and discussion}

In the time of shaping the global culture, it is important to draw attention to the real process of creating the layer of common symbols of a global culture. In this process, a key role belongs to the creative approach. The subjects of international communication will be able to free themselves from prejudices, stereotypes and other barriers if they use creative thinking to foreign cultures. Effective intercultural communication should have elements of creativity (Braslauskas, 2020). As Braslauskas writes:

"Effective intercultural constructive communication is impossible if we do not perceive the barriers to intercultural interaction and do not know the ways of removing them" (2020, p. 208).

To overcome cross-cultural barriers in terms of translating the cultural code of a message from a foreign culture into the language of your own culture, you can use creative digital technologies. It is digital technologies, that can help create a platform for intercultural communication in terms of forming a system of symbols of global culture.

The author assumes that the digital platforms can be served as basis for creating a common global system of symbols of different levels (ethnic, national, transnational) and types (religious, political, legal, etc.). Currently, various subjects of cross-cultural communication (bloggers, researchers, organizations, publishers, libraries, etc.) create electronic dictionaries, reference books, encyclopedias, and even platforms for discussing the about the universal meanings of the particular symbols. For example, Wikipedia.org (2020), Symbols.com (2020), Nationalpedia.org (2020). It is relevant to create a universal "cultural knowledge network" on the creative digital platform. It can be relevant step to help all people all over the world to fond common points for understanding. 
Therefore, it is actual to use creative approach of development of digital technologies for breaking the intercultural barriers. However, we need the efforts of researchers and teachers, public and state leaders, international and national organizations to discuss on the assignment of particular meanings to the symbols of the global layer of world culture. Furthermore, namely the creative digital technologies can help create a digital platform for intercultural communication in terms of forming a system of symbols of global culture. It is possible that the upper layer of global culture in the form of a system of consent key symbols can be considered as one of the drivers for shaping of "the third culture". Remarkably, that the third culture is harmonized in the realm in which people may communicate beyond their original culture (Casrnir, 1999; Fong \& Chuang, 2003). The third culture is

"a mutually shared space where members of all cultures can transcend their cultural borders to interact on the basis of shared values and beliefs to reaffirm their unique identities and voices" (Patel et al., 2011, p. 154).

Metaphorically, a globe culture can be depicted as a giant tree, the crown of which grows up and is intertwined at the expense of the branches of a great number of cultures. The upper layer of culture (system of "condensation", "key", "core" symbols) is the mechanism that help the achieve mutual understanding different cultures.

Surely, subjects of cross-cultural communication will achieve a greater mutual understanding if they have the common creative language for communication. In this case, we are referring to the symbol language. All countries are assigned to the task of forming an agreed meaning of the particular symbols. It is crucial to develop a dynamic, multi-level creative model of culture: from the micro-level of the individual to the macro level of a global culture. Cultural symbols reflect what is happening in society and contribute to rethinking the way it works. Spreading common symbols, introducing common holidays, teaching a common understanding of world history help to construct the super national global identity in the context of evolution perspective of cultural knowledge network. Shaping a creative symbolic system of a global culture, the access to which will help the participants of transcultural communication to minimize the barriers that prevent the most effective mutual understanding in future.

Currently, it is urgent to construct a common code to the global cultural language in the time of pandemic for coherence among various contries in solving critical problems. For shaping the system of common symbols of a global culture is necessary to create educational and reference materials that will be posted on online creative platforms, and the latest digital technologies will help to "break" access to different cultural codes of other peoples and cultures. The development of a common "layer" of culture as system of concepts, knowledge, ideals, norms, values, beliefs, patterns is the relevant way for acievement of mutual understanding among countries in solving global problems that pose a threat to all humanity.

There is a need to ensure the information support and broadcast the cultural symbols of the different social (ethnic, religious, cultural, political, etc.) groups and organization of each state of the world. At secondary and higher school each person has to know and respect the multicultural diversity of the different ethnic and social group, nations by studying meanings of the symbols of the particular world cultures. The new symbolic systems of different social communities, countries and regions have been creating. In a changing world there 
is increasingly necessary to search the meanings of the symbols which can bind all ethnic, social and regional communities together on the values of tolerance, trust and openness to cooperation. The study of symbols of modern global integration is important to understanding of how the layer of world culture shaping as social-cultural reality. This research may serve as a foundation for the further analysis of the national policy dealing with the issues of international communication.

\section{Conclusions}

In conclusions, it is necessary to note that the contemporary society is characterized by increase, acceleration and globalization of social communications. The globalization process generates new creative forms and means of intercultural interaction, which make scholars rethink traditional concepts, theories and approaches. In this context, there is a growing awareness of the need to generalize the knowledge accumulated in the practice of interaction between cultures, to more accurately identify cross-cultural differences, features of cultures, to reveal the mechanisms of cross-cultural communication and factors that contribute to achieving mutual understanding between the subjects of interaction. The solution of these tasks will help to outline the contours of the modern creative model of intercultural communication, which will indicate the points of demarcation of information's flows, demonstrate ways to select the most important points of interaction, aimed at minimizing barriers in the process of interaction of subjects, taking into account the index of their cultural distance. One should further develop these issues in detail as making an effective intercultural dialogue is the necessary condition for the mankind survival at this time.

The knowledge of the symbol systems of a global culture can help all peoples to open new perspective of transcultural communication in the context of creation common non-verbal language for mutual understanding.

\section{References}

Barthes, R. (1994). The semiotic challenge. University of California Press.

Beck, U. (2008). World risk society. Polity Press.

Betancourt, M. (2015). The critique of digital capitalism: An analysis of the political economy of digital culture and technology. Punctum Books.

Braslauskas, J. (2020). Effective creative intercultural communication in the context of business interaction: Theoretical and practical aspects. Creativity Studies, 13(1), 199-215. https://doi.org/10.3846/cs.2020.12094

Casrnir, F. L. (1999). Foundations for the study of intercultural communication based on a third-culture building model. International Journal of Intercultural Relations, 23(1), 91-116. https://doi.org/10.1016/S0147-1767(98)00027-3

Cassirer, E. (1955). The philosophy of symbolic forms, Vol. 1: Language. Yale University Press.

Castells, M. (2010). The information age: Economy, society, and culture, Vol. I: The rise of the network society. A John Wiley \& Sons, Ltd.

Charon, J. M. (2009). Symbolic interactionism: An introduction, an interpretation, an integration. Pearson College Div. 
Dodd, C. H. (1977). Perspectives on cross-cultural communication. Kendall Hunt Publishing Company.

Doherty, S. (2016). The impact of translation technologies on the process and product of translation. International Journal of Communication, 10, 947-969. https://ijoc.org/index.php/ijoc/article/viewFile/3499/1573

Dreyfuss, H. (1984). Symbol sourcebook: An authoritative guide to international graphic symbols. John Wiley \& Sons, Inc.

Eko, U. (2006). Otsutstvujushhaja struktura. Vvedenie v semiologiju. Symposium.

Ferguson, N. (2012). Civilization: The West and the rest. Penguin Books.

Ferraro, G., \& Andreatta, S. (2018). Cultural anthropology: An applied perspective. Cengage Learning.

Floridi, L. (2014). The fourth revolution: How the infosphere is reshaping human reality. Oxford University Press.

Floridi, L. (Ed.) (2015). The Onlife Manifesto: Being human in a hyperconnected era. Springer. https://doi.org/10.1007/978-3-319-04093-6

Fong, M., \& Chuang, R. (Eds.). (2003). Communicating ethnic and cultural identity. Rowman \& Littlefield Publishers.

Foret, F. (2009). Symbolic dimensions of EU legitimization. Media, Culture and Society, 31(2), 313-324. https://doi.org/10.1177/0163443709103777

Fornäs, J. (2012). Signifying Europe. Intellect Ltd. https://doi.org/10.2307/j.ctv9hj915

Geertz, C. (2017). The interpretation of cultures. Basic Books.

Giddens, A. (1986). The constitution of society. University of California Press.

Gokmen, G. (2019). Clash of civilizations demystified. European Journal of Political Economy, 60. https://doi.org/10.1016/j.ejpoleco.2018.08.011

Graber, D. A. (1976). Verbal behavior and politics. University of Illinois Press.

Gudykunst, W. B. (1997). Cultural variability in communication: An Introduction. Communication Research, 24(4), 327-348. https://doi.org/10.1177/009365097024004001

Guirdham, M., \& Guirdham, O. (2017). Communicating across cultures at work. Macmillan Education \& Palgrave. https://doi.org/10.1057/978-1-137-52637-3

Hall, S. (1997). The work of representation. In S. Hall (Ed.), Culture, media and identities. Representation: Cultural representations and signifying practices (pp. 13-74). SAGE Publications \& Open University.

Hall, E. T., \& Reed Hall, M. (1987). Hidden differences: Studies in international communication. Japan for Americans. Bungei Shunju.

Hofstede, G. (1984). Cross-cultural research and methodology series: Vol. 5. Culture's consequences: International differences in work-related values. SAGE Publications, Inc.

Huntington, S. P. (1997). The clash of civilizations and the remaking of world order. Penguin Books.

Hurn, B., \& Tomalin, B. (2013). Cross-cultural communication: Theory and practice. Palgrave Macmillan. https://doi.org/10.1057/9780230391147

Inglehart, R. F. (2018). Cultural evolution: People's motivations are changing and reshaping the world. Cambridge University Press. https://doi.org/10.1017/9781108613880

Inoguchi, T. (2007). Clash of values across civilizations, R. J. Dalton \& H.-D. Klingemann (Eds.), The Oxford handbooks of political science. The Oxford handbook of political behavior (pp. 240-258). R. E. Goodin (General Ed.). Oxford University Press. https://doi.org/10.1093/oxfordhb/9780199270125.003.0013

James, P., \& Steger, M. B. (2014). A genealogy of “Globalization": The career of a concept. Globalizations, 11(4), 417-434. https://doi.org/10.1080/14747731.2014.951186

Jung, C. G. (1980). The collected works of C. G. Jung: Vol. 18. The symbolic life: Miscellaneous writings. G. Adler \& R. F. C. Hull (Eds.). Princeton University Press. 
Kačerauskas, T. (2017). Kreativnost' i koncepcija kreativnogo obshhestva. Sociologicheskie issledovanija, $10,26-35$.

Kim, Y. Y. (1988). Communication and cross-cultural adaptation. Multilingual Matters Ltd.

Kim, Y. Y. (2005). Inquiry in intercultural and development communication. Journal of Communication, 55(3), 554-577. https://doi.org/10.1111/j.1460-2466.2005.tb02685.x

Laffan, B. (1996). The politics of identity and political order in Europe. Journal of Common Market Studies, 34(1), 81-102. https://doi.org/10.1111/j.1468-5965.1996.tb00561.x

Lévi-Strauss, C. (1974). Structural anthropology. Basic Books.

Lotman, Y. M. (2001). Universe of the mind: A semiotic theory of culture. Indiana University Press.

Luhmann, N. (1997). Globalization or world society: How to conceive of modern society. International Review of Sociology, 7(1), 67-79. https://doi.org/10.1080/03906701.1997.9971223

Macionis, J. J. (2014). Society: The basics. Pearson.

Manners, I. (2011). Symbolism in European integration. Comparative European Politics, 9, 243-268. https://doi.org/10.1057/cep.2010.11

McLuhan, M. (2002). The Gutenberg galaxy: The making of typographic man. University of Toronto Press.

Melnikas, B. (2019). Sustainable social development, economic growth and technological breakthroughs: Creativity and creative change. Creativity Studies, 12(2), 301-314. https://doi.org/10.3846/cs.2019.10335

Merelman, R. M. (Ed.). (2018). Language, symbolism, and politics. Routledge. https://doi.org/10.4324/9780429040818

Morain, G. G. (2001). Kinesics and cross-cultural understanding. In J. M. Valdes (Ed.), Culture bound: Bridging the cultural gap in language teaching (pp. 64-76). Cambridge University Press.

Multitran.com. (2020). Multitran. https://www.multitran.com/

Nationalpedia.org. (2020). National Pedia. https://nationalpedia.org/

Ortner, Sh. B. (1973). On key symbols. American Anthropologist, 75(5), 1338-1346. https://doi.org/10.1525/aa.1973.75.5.02a00100

Patel, F., Li, M., \& Sooknanan, P. (2011). Building a global community. In F. Patel, M. Li, \& P. Sooknanan, Intercultural communication: Building a global community (pp. 5-14). SAGE Publications Pvt. Ltd.

Peoples, J., \& Bailey, G. (2015). Humanity: An introduction to cultural anthropology. Cengage Learning.

Proz.com. (1999-2020a). KudoZ ${ }^{\text {sw }}$ translation help network. https://www.proz.com/about/overview/kudoz/

Proz.com. (1999-2020b). Online community and workplace for language professionals. https://www.proz.com/

Robertson, R. (2000). Theory, culture and society. Globalization: Social theory and global culture. M. Featherstone (Ed.). SAGE Publications. https://doi.org/10.4135/9781446280447

Samovar, L. A., Porter, R. E., McDaniel, E. R., \& Roy, C. S. (2017). Communication between cultures. Cengage Learning.

Samovar, L. A., Porter, R. E., McDaniel, E. R., \& Sexton Roy, C. (2015). Intercultural communication: $A$ reader. Cengage Learning.

Schneider, D. M. (1980). American kinship: A cultural account. The University of Chicago Press. https://doi.org/10.7208/chicago/9780226227092.001.0001

Schwartz, Sh. H., \& Sagie, G. (2000). Value consensus and importance: A cross-national study. Journal of Cross-Cultural Psychology, 31(4), 465-497. https://doi.org/10.1177/0022022100031004003

Sdltrados.com. (2020). SDL Trados. https://www.sdltrados.com/

Sitaram, K. S. (1976). Foundations of intercultural communication. Charles E. Mercill Publishing Company. 
Stasiulis, N. (2017). The idea of the creative society and the development of creative industries. Journal of Scientific Papers: Economics and Sociology, 10(2), 217-226.

https://doi.org/10.14254/2071-789X.2017/10-2/16

Stewart, E. C. (1973). Outline of intercultural communication. Report Submitted to the Business Council for International Understanding, American University. Business Council for International Understanding, The American University.

Stratton, G., \& Northcote, J. (2016). When totems beget clans: The brand symbol as the defining marker of brand communities. Journal of Consumer Culture, 16(2), 493-509. https://doi.org/10.1177/1469540514528194

Swidler, A. (1986). Culture in action: Symbols and strategies. American Sociological Review, 51(2), 273-286. https://doi.org/10.2307/2095521

Symbols.com. (2020). Symbols. https://www.symbols.com/

Ten, Y. (2014). The symbolic system of the contemporary Europe: Its meaning and role in the construction of the European identity. Societal innovations for Global Growth, 1(3), 4-12.

Theiler, T. (2006). Political symbolism and European integration. Manchester University Press.

Translatorsbase.com. (2002-2020). Translation jobs for freelance translators and translation agencies. https://www.translatorsbase.com/

Translatorscafe. (2002-2021). Translators Café. https://www.translatorscafe.com/cafe/

Triandis, H. C. (2018). New directions in social psychology. Individualism and collectivism. R. W. Nisbett (Series Ed.). Routledge. https://doi.org/10.4324/9780429499845

Turner, V. (1970). The forest of symbols: Aspects of Ndembu Ritual. Cornell University Press. https://doi.org/10.1007/978-1-349-15388-6_8

United Nations. (2020). Treaty on the Non-Proliferation of Nuclear Weapons (NPT). https://www.un.org/ disarmament/wmd/nuclear/npt/text/

United Nations Educational, Scientific and Cultural Organization. (1995). Declaration of principles on tolerance. http://portal.unesco.org/en/ev.php-URL_ID=13175\&URL_DO=DO_TOPIC\&URL_SECTION=201.html

United Nations Educational, Scientific and Cultural Organization. (1948). Universal Declaration of Human Rights. http://portal.unesco.org/en/ev.php-URL_ID=26053\&URL_DO=DO_TOPIC\&URL_ SECTION=201.html

White, L. A. (1940). The symbol: The origin and basis of human behavior. Philosophy of Science, 7(4), 451-463. https://doi.org/10.1086/286655

Wikipedia.org. (2020). Wikipedia: The free encyclopedia. https://www.wikipedia.org/

Wordfast.com. (2020). Wordfast. https://www.wordfast.com/

Zakon Respubliki Belarus'. (2021). Ob izmenenii Zakona Respubliki Belarus' “O gosudarstvennyh simvolah Respubliki Belarus"'. Nacional'nyj pravovoj Internet-portal Respubliki Belarus'. https://pravo. by $/$ document $/$ ?guid $=12551 \& \mathrm{p} 0=\mathrm{H} 12100083 \& \mathrm{p} 1=1 \& \mathrm{p} 5=0$ 